Mini Review

\title{
OVERVIEW OF LINSEED PRODUCTION IN BOSNIA AND HERZEGOVINA
}

\author{
Miloš Nožinić*, Bojan Rajčević*, Duško Jović**, Linda Kluga***, Tanja Malčić*, \\ and Vesna Bojić* \\ * Agricultural Institute of the Republic of Srpska Banja Luka, Knjaza Miloša 17, Republic of Srpska, BOSNIA AND HERZEGOVINA; \\ milosn@blic.net \\ ** Faculty of Medicine, University of Banja Luka, Save Mrkalja 14, Banja Luka, Republic of Srpska, BOSNIA AND HERZEGOVINA \\ ${ }^{* * *}$ Faculty of Biology, University of Latvia, Kronvalda bulv. 4, Riga LV-1586, LATVIA
}

Communicated by Isaak Rashal

\begin{abstract}
Linseed (Linum usitatissimum L.), as one of the richest sources of omega-3 fatty acids, antitumoral phytoestrogens and plant mucilage, has great importance for human health. For this reason, the Agricultural Institute of Republic of Srpska promotes linseed production and processing through practical research activities. This paper provides an overview of linseed production and research activities on linseed since 2004, when this crop was returned into production in Bosnia and Herzegovina. The most important findings regarding linseed production and quality in recent years are discussed. So far, it seems that organic linseed production has better perspective in mountain regions compared to lowlands, mainly due to lack of invasive weeds $500 \mathrm{~m}$ above sea level. Until now, linseed diseases that can spoil the quality of seed, have not been recorded, due to extensive linseed production. The first comprehensive technological analyses of cold extracted linseed oil from the mountain region Petrovac showed unique quality characteristics. This mountain region is well known for its virgin nature and sunny microclimate. This has resulted in increased interest for linseed oil, as well as raised the price of domestic linseed oil.
\end{abstract}

Key words: linseed, linseed oil, organic production, unique quality, human health.

\section{INTRODUCTION}

Flax/linseed is an ancient crops that has been grown in many regions as an important fibre, oil and food source. The oldest flax findings date from Kavkaz 35000 years ago (Kvavadze et al., 2009). It is fascinating that some of these fibres were coloured and cut, indicating "advanced" technologies in the dawning of mankind. Using molecular methods, Danish scientists have proved growing of fibre and oil flax (linseed) forms in Denmark even 1600 years BC (Allaby et al., 2005; Runge and Henriksen, 2007).

The health traits of flax/linseed have been known to almost all civilizations. Flax clothing dominated in warm regions of ancient Mesopotamia and Egypt, as it offered ideal skin protection. Lignin in flax fibres is an excellent absorbent of ultraviolet radiation (Zimniewska et al., 2004). Numerous inscriptions in Sumerian clay tablets show that flax (sumerian "gu") had great importance for dressing, diet and healing. The multifunctional role of flax/linseed has been recorded on papyrus and wall drawings dating from all Pharaoh dynasties. Hippokrates (460-377 BC) successfully healed intestinal diseases with linseed. Respecting the im- portance of linseed oil for Russian dietary and healing needs, the emperor Peter the Great banned linseed exports.

Before the 1960's, flax/linseed was grown throughout the Balkan region organically. In that period, organic production was easier than today due to availability of rural labour. Unfortunately, flax/linseed production in the Balkan region was discontinued in the 1960's when cheap synthetic fibres replaced natural ones.

The interest for linseed products has been increasing after the recognition of the irreplaceable role of essential fatty acids and their acid derivates (DHA, EPA) for the structure and function of the neuro- and cardiovascular systems. About one half of population in the Balkan region suffers mortality due to consequences of irregular lipid status, which is (among other factors) the result of essential fatty acid deficit. Flax is the richest source of linolenic fatty acid (omega-3), which plays a key role for proper neuro- and cardiovascular functions.

The beneficial influence of linseed/flax products on human health has been an important subject of many multidisciplinary studies (Prasad, 1997; Simopoulos, 1999; Dahl et 
al., 2005). Linseed contains 600-800 times more lignans than other oil crops (Westcott et al., 2001). Lignans belong to phytoestrogens, which in a natural way compensate estrogen deficit in menopausa, reducing risk of mammal cancer (Thompson, 1998). Flax fibre (linen) can increase the alfa-immunoglobulin content in humans and result in lower miographic tension of muscles, lower body temperature and sounder sleep (Kozlowski, 2001; Zimniewska et al., 2004). An extended list of scientific studies about linseed/flax curative traits confirms the importance of this crop, which has been neglected in Balkan region for half of one century.

The FAO International Conference "Natural Fibres for Healthy Life", held in Banja Luka in October 2004 had a key role for launching of research activities on linseed in Bosnia and Herzegovina. This Conference was organised by the Agricultural Institute of Republic of Srpska and the Institute for Natural Fibres in Poznan, where coordination centre of the FAO European Cooperative Research Network on Flax and other Bast Plants is located.

In the frame of organising the Conference, linseed was returned into production in Bosnia and Herzegovina. The title of this scientific event symbolically defines the directions of the research and practical activities in the future. All these activities will aid health benefits through increased consumption of domestic linseed products. The processing of flax fibres is presently limited, as the domestic textile industry has not yet adapted to thus product.

The research activities, as well as an educational programme conducted by the Agricultural Institute of Republic of Srpska, have raised interest of farmers and buyers for domestic linseed and linseed products. Recently, cold extracted linseed oil has attracted farmer interest due to its high market price. In spring 2013, a few animal farms started growing linseed in order to produce meat and eggs with increased content of omega-3 fatty acids.

\section{LINSEED PRODUCTION AND RESEARCH ACTIVI- TIES IN 2004}

In 2004, the linseed variety 'Olin' was introduced into production in Bosnia and Herzegovina through a network of demonstration trials. These trials occurred at 20 locations, representing different agroecological conditions from 100 to $700 \mathrm{~m}$ above sea level. More detailed data were available from 16 locations (Table 1). The size of production plots varied from 0.5 to 1 ha. Two Czech fibre flax varieties ('Jitka' and 'Venica') were included in demonstration trials at locations Banja Luka and Drinić in 2004. The agrotechnology was adapted for each trial depending on climate conditions and soil fertility $(\mathrm{pH}$, humus content, available $\mathrm{P}_{2} \mathrm{O}_{5}$, and $\mathrm{K}_{2} \mathrm{O}$ ) The nitrogen treatment varied from 15 to $62 \mathrm{~kg} / \mathrm{ha}$. Field observations were focused on basic agronomic traits and the most important factors in practical production (weeds, harvest). Herbicides (bentazon) were recommended for plots where risk of weed development was observed. This treatment was particularly needed in the Brčko region, where the land had not been cultivated for a longer period due to migration of farmers in the war and post-war period.

The highest linseed yield (2.5 t/ha) was obtained at Šereg Ilova (Table 1). Excellent seed purity at this location was due to high herbicide efficiency. In the organic production system used in the neighboring village Velika Ilova, the yield was only $500 \mathrm{~kg} / \mathrm{ha}$ with $10 \%$ weed seed impurity.

Table 1

RESULTS OF DEMONSTRATION LINSEED/FLAX TRIALS IN BOSNIA AND HERZEGOVINA IN 2004

\begin{tabular}{|c|c|c|c|c|c|c|}
\hline No. & Municipality & Location & Alt. & Yield, kg/ha & $\mathrm{Cd} \mathrm{mg/kg}$ & Problem \\
\hline 1. & Banja Luka & Agricultural School & 150 & 1080 & - & difficult harvesting \\
\hline 2. & Banja Luka & Agricultural Institute & 150 & \multicolumn{3}{|c|}{ Fiber variety Jitka- 800 kg/ha, fiber variety Venica- 810 kg/ha } \\
\hline 3. & Banja Luka & Stričići & 700 & 1320 & 0.50 & high soil acidity \\
\hline 4. & Prnjavor & Šereg Ilova & 240 & 2500 & 0.54 & - \\
\hline 5. & Prnjavor & Velika Ilova & 220 & 500 & 0.39 & Ambrosia artemisifolia \\
\hline 6. & Prnjavor & Potočani & 300 & 1220 & 0.58 & harvesting \\
\hline 7. & Prnjavor & Vijačani & 330 & 1000 & 0.16 & grass weeds \\
\hline 8. & Prnjavor & Štrpci & 100 & 500 & 0.57 & lodging, grass weeds \\
\hline 9. & Brčko & Boderište & 140 & 1390 & 1.06 & - \\
\hline 10. & Brčko & Donje Dubrave & 120 & 1380 & 0.54 & Ambrosia artemisifolia \\
\hline 11. & Brčko & Omerbegovača & 120 & 1270 & 0.92 & Ambrosia artemisifolia \\
\hline 12. & Brčko & Bukvik & 120 & 870 & 0.44 & Ambrosia artemisifolia \\
\hline 14. & Brčko & Cerik & 150 & 700 & - & Ambrosia artemisifolia \\
\hline 15. & Brčko & Brezovo polje & 96 & 200 & - & various weeds \\
\hline 16. & Drinić & Drinić (fibre variety) & 700 & Fiber variety Jitka- $810 \mathrm{~kg} / \mathrm{ha}$ & & \\
\hline 17. & Petrovac & Vrtoče & 600 & 1.000 & - & disabled harvesting \\
\hline 18. & Gradiška & Kućište & 100 & 400 & - & Ambrosia artemisifolia \\
\hline \multicolumn{3}{|c|}{ Average yield-cultivar Olin } & & 1014 & & \\
\hline
\end{tabular}


Significant lodging $(80 \%)$ was observed at Štrbci, while at other locations it was recorded as $50 \%$. Because of old combines, harvest was quite difficult at seven locations. Twophase harvest caused loss of seed by $10-30 \%$.

Fibre flax varieties at Banja Luka and Drinić were sampled for grain yield (Table 1), fibre yield and quality. The Czech fibre variety 'Jitka' produced the highest average straw yield $(5800 \mathrm{~kg} / \mathrm{ha})$ in micro trials for the period 2008-2010, which was significantly higher the the average of all trials (Table 2).

Table 2

THE STRUCTURE OF FATTY ACIDS (\%) IN THE COLD PRESSED LINSEED OIL-PANONIAN CULTIVAR

\begin{tabular}{c|c|c|c|c|c|c|c}
\hline FFA & C16:0 & C16:1 & C18:0 & C18:1 & C18:2 & C18:3 & C20:0 \\
\hline 0.57 & 5.71 & 0.65 & 3.68 & 17.62 & 14.25 & 57.55 & 0.16
\end{tabular}

Micro trials in 2004 included 26 genotypes placed in four replications randomly. Plot size was $5 \mathrm{~m}^{2}$. The average linseed yield in the micro trials was $1074 \mathrm{~kg} / \mathrm{ha}$. It is interesting that the highest linseed yield of $2500 \mathrm{~kg} / \mathrm{ha}$, obtained at Šereg Ilova, was significantly higher than the average (1074 $\mathrm{kg} / \mathrm{ha})$ and maximal yield $(1740 \mathrm{~kg} / \mathrm{ha})$ in the micro trial in Banja Luka in that year (Garić and Mandić, 2004). Usually, under similar agroecological conditions and similar agrotechnology, seed yields in micro trials significantly exceed seed yields in demonstration trials. Therefore, as the obtained rank in yield is illogical, reasons for this trend need to be answered. Possibly, this was due to very different soil traits and increased activity of microelements in producing yield.

The fertile alluvial soil in Banja Luka has neutral reaction ( $\mathrm{pH}$ in water, 7.1), 2.6\% humus content, very high concentration of available $\mathrm{P}_{2} \mathrm{O}_{5}(35 \mathrm{mg} / 100 \mathrm{~g})$ and high $\mathrm{K}_{2} \mathrm{O}$ conconcentration $(45 \mathrm{mg} / 100 \mathrm{~g})$. The soil in Šereg Ilova is pseudoclay with moderate acidity ( $\mathrm{pH}$ in water, 5.3), $3.4 \%$ humus content, very low concentration of available $\mathrm{P}_{2} \mathrm{O}_{5}$ $(2.3 \mathrm{mg} / 100 \mathrm{~g})$ and high $\mathrm{K}_{2} \mathrm{O}$ concentration $(21.7 \mathrm{mg} / 100$ g). Moderate acid soils ( $\mathrm{pH}$ 5-6) with lower concentration of available $\mathrm{P}_{2} \mathrm{O}_{5}$, as in Šereg Ilova, contain higher concentration of available zinc, which has a very positive effect on linseed/flax yield (Moraghan, 1980; Jankauskiene, 2001). Most microelements are more available in acid soils, which occupy about $60 \%$ of the arable land in Bosnia and Herzegovina. For this reason, the effect of microelements on yield of flax should be studied more detailed. In the 2004 , the economically profitable yield was over 1.000 $\mathrm{kg} / \mathrm{ha}$.

High concentration of the heavy metal cadmium in food is a serious risk factor for renal disease (Vapa, M. and Vapa Lj., 1997). In 2004, the cadmium concentration was determined in the products to provide information for debates in the international conference held in Banja Luka. According to EU regulations, the acceptable level of cadmium in edible oil is $0.50 \mathrm{mg} / \mathrm{kg}$. Cadmium concentration in linseed oil from 10 locations (cultivar 'Olin') in Bosnia and Herzegovina in 2004 ranged from $0.16-1.06 \mathrm{mg} / \mathrm{kg}$ (Table 1). In that same year, in the micro trial with 26 linseed genotypes at Banja Luka, the concentration of cadmium in oil ranged from $0.31-0.60 \mathrm{mg} / \mathrm{kg}$. Higher accumulation of cadmium was observed in vegetative plant parts (fibres). In some cases, higher cadmium concentration in fibres can present a serious risk for skin health (Lukipudis, 2001).

\section{LINSEED PRODUCTION CONSTRAINTS}

Weeds have been the most important problem in the practical linseed production since 2004. Linseed yield and seed purity mainly depended on the weed spectrum and development. The period for herbicide application of linseed is quite short, when crop height is from 8 to $12 \mathrm{~cm}$, which is an additional problem.

In the period 2005-2010, a few farmers attempted organic linseed production in the lowlands, but weeds resulted in a halt of this. Ambrosia artemisifolia, Convolvulus arvensis and Cirsium arvense have been the most common weeds in lowland regions. In contrast to lowlands, in the mountain regions over $600 \mathrm{~m}$ a.s.1., organic linseed production has been easier, mainly because of the absence of Ambrosia artemisifolia (Nožinić et al., 2009; Nožinić et al., 2012). In 2008 , the variety Olin was grown organically at the mountain location Sitnica $(750 \mathrm{~m})$. The soil was enriched by sheep manure, and the problem of weed patches was solved by manual weeding.

Spread of thermopile invasive weeds has been promoted by climate warming in the recent two decenniums (Trkulja et al., 2010; Nožinić et al., 2012). Similar changes of weed distributions have been observed in Poland during a 30-year period (Heller, 2001).

Climate change effects have become more and more evident on linseed/flax production. Unfavourable weather conditions in 2007 caused lack of of linseed in subsequent years. April 2007 was recorded as the driest $\left(51 / \mathrm{m}^{2}\right)$ in Banja Luka since 1961. Because of drought, linseed emerged unevenly with significantly reduced number of plants. Mean temperature in April $\left(14.2^{\circ} \mathrm{C}\right)$ and May $\left(19.2^{\circ} \mathrm{C}\right)$ in that year was the warmest in meteorological records at Banja Luka.

Late frosts present risk for linseed production in mountain valleys. It was encouraging that linseed (in the phase of coleoptiles) at Vrtoče $(600 \mathrm{~m})$ survived (with small damage) at a minimal temperature of $-8{ }^{\circ} \mathrm{C}$ (April 10, 2012). The local authors noted that young linseed plants can withstand temperatures to $-5^{\circ} \mathrm{C}$ (Jevtić, 1986; Kocjan, 1999).

The main problem is the lack of the high yielding linseed cultivars. So far, Bosnia and Herzegovina has not adopted the EU cultivar list, which makes seed exchange difficult. 


\section{BETTER TIME FOR LINSEED AND LINSEED OIL PRODUCERS}

In 2011, organic linseed and linseed oil production was carried out successfully in the mountain valley Vrtoče in the municipality Petrovac $(600 \mathrm{~m})$. The variety originated from Srbija, but the name of the variety was not known. The production of the linseed was based on liquid cow manure.

The advantages for organic production in the Petrovac region are: unpolluted soils, moderate temperatures during the vegetation period, over 2.000 sunny hours per year, high precipitation $\left(1.200-1.3001 / \mathrm{m}^{2}\right)$, frequent winds and absence of the invasive weed Ambrosia artemisifolia.

The content of free fatty acids (FFA) in the cold extracted oil was $0.57 \%$ (Table 2), which is significantly lower than the maximum allowed content of $3 \%$. A very low peroxide concentration of $0.65 \mathrm{mmol} \mathrm{O}_{(2)} / \mathrm{kg}$ confirmed the excellent quality of cold extracted oil (Table 3 ). The analysis of microbiological oil status showed absence of bacteria.

Table 3

THE PARAMETERS OF LINSEED OIL QUALITY-PANONIAN CULTIVAR

\begin{tabular}{|c|c|c|c|}
\hline Characteristic & Determined & $\begin{array}{c}\text { Maximum } \\
\text { allowed }\end{array}$ & Method \\
\hline $\begin{array}{l}\text { Peroxide concen- } \\
\text { tration number }\end{array}$ & $\underset{f / k g}{0.65 \mathrm{mmol} \mathrm{O}_{(2)}}$ & $\underset{\text { ulja }}{10 \mathrm{mmol} \mathrm{O}_{(2)} / \mathrm{kg}}$ & ISO 3960 \\
\hline $\begin{array}{l}\text { Water and other } \\
\text { evaporable sub- } \\
\text { stances }\end{array}$ & $0.02 \%$ & do $0.4 \%$ & ISO 662:1998 \\
\hline Phosphorus & $7.90 \mathrm{ppm}$ & No limits & $\begin{array}{c}\text { A.O.C.S. Ca } \\
12-55\end{array}$ \\
\hline $\begin{array}{l}\text { Non soapy sub- } \\
\text { stances }\end{array}$ & $5.16 \mathrm{~g} / \mathrm{kg}$ & $15 \mathrm{~g} / \mathrm{kg}$ & ISO 3596-2:1998 \\
\hline $\begin{array}{l}\text { The content of in- } \\
\text { soluble impurity }\end{array}$ & $0.01 \%$ & $0.05 \%$ & ISO 663 \\
\hline
\end{tabular}

Due to environmental advantages and proper agrotechnology, weeds did not appear, and thus the linseed was exceptionally pure. Weed seeds and impurities (soil dust, gasses absorbed during harvesting) can change the taste and smell of cold extracted oil.

So far, stronger infestation with common linseed diseases, like Fusarium wilt, has not been recorded in Bosnia and Herzegovina, which is extremely important for linseed and linseed oil quality. This is mainly due to the current extensive linseed production at several distant locations (regions). This status of uncontaminated seed should be maintained as longer as possible. Flax disease was described by local authors during the period when flax occupied a large area in Balkan countries (Panjan, 1968).

The organic production on the farm in Vrtoče, which was associated with high quality traits, as well as and educational programme (by the Agricultural Institute of Republic of Srpska) led to a price of 20 euros per litre of linseed oil.
Bearing in mind the obtained yields of 1.4 t/ha in 2011 and 2012, this yield had very high economic value.

The sowing area of linseed in spring 2013 will be higher than in previous years due to the good results on the farm in Vrtoče. It seems that raised awareness of the importance of omega three fatty acids, phyto estrogens as well as other linseed healing components has led to a better time for linseed producers.

\section{REFERENCES}

Allaby, R. G., Peterson, G. W., Merriwether, D. A., Fu, Y. B. (2005). Evidence of the domestication history of flax (Linum usitatissimum L.) from genetic diversity of the sad2 locus. Theor. Appl. Genet., 112, 58-65.

Brutch, N. B. (2002). The flax genetic resources collection held at the Vavilov Institute, Russian Federation. In: Collection of Papers from Ad hoc meeting Flax Genetic Resources in Europe, 7-8 December 2001 (pp. 61-66). Prague, Czech Republic: International Plant Genetic Resources Institute, Rome.

Dahl, W. J., Lockert, E. A., Cammer, A. L., Whiting, S. J. (2005). Effects of flax fiber on laxation and glycemic response in healthy volunteers. J. Med. Food, 8 (4), 508-511.

Garić, K., Mandić, D. (2004). Experimental production of flax seed in Bosnia and Herzegovina in 2004. In: Proceedings of the Third Global Workshop "Natural Fibers for Healthy Life", 24-28 October 2004 (CD form). Banja Luka, Bosnia and Herzegovina: FAO European Cooperative Research Network on Flax and other Bast Plants.

Heler, K. (2001). Monitoring and prognosis of weed infestation of fibre flax in Poland. In: Proceedings of the Second Global Workshop "Bast Plants in the New Millennium”, 3-6 June 2001 (pp. 286-288). Borovets, Bulgaria: Coordination Centre of the FAO European Cooperative Research Network on Flax and other Bast Plants at the Institute of Natural Fibres, Poznan, Poland.

Jankauskiene, Z.(2001). Zinc and phosphorus: Influence on flax yield. In: Proceedings of the Second Global Workshop "Bast Plants in the New Millennium”, 3-6 June 2001 (pp. 219-228). Borovets, Bulgaria: Coordination Centre of the FAO European Cooperative Research Network on Flax and other Bast Plants at the Institute of Natural Fibres, Poznan, Poland.

Jevtić, S. (1986). Flax. In: Special Field Crops (pp. 185-200). Beograd: Scientific book (in Serbian).

Kvavadze, E., Ofer, Bar-Y., Belfer-Cohen Anna, Boaretto Elisabetta, Jakeli, N., Matskevich, Z., Meshveliani, T. (2009). 30.000-Year-old wild flax fibers. Science, 325 (5946), p. 1359.

Kocjan, A. D. (1999). Flax. In: Forgotten Field Crops (pp. 83-99). Ljubljana: Farmers' Voice (in Slovenian).

Kozlowski, R. (2001). Future Trends in the Production, Processing and Application of Natural Fibers. In: Proceedings of the Second Global Workshop "Bast Plants in the New Millennium”, 3-6 June 2001 (pp. 15-31). Borovets, Bulgaria: Coordination Centre of the FAO European Cooperative Research Network on Flax and other Bast Plants at the Institute of Natural Fibres, Poznan, Poland.

Lukipudis, Z. (2001). Selectivity of some sorts of flax and common contamination of flax fibers by heavy metals. In: Proceedings of the Second Global Workshop "Bast Plants in the New Millennium", 3-6 June 2001 (pp. 215-218). Borovets, Bulgaria: Coordination Centre of the FAO European Cooperative Research Network on Flax and other Bast Plants at the Institute of Natural Fibres, Poznan, Poland.

Moraghan, J. (1980). Effects of soil temperature on response of flax to phosphorus and zinc fertilizers. Soil Sci., 5, 290-296.

Nožinić, M., Marković, M., Trkulja, V. (2009). Experimental Linseed Oil Production in Banja Luka Region. In: Scientific Bulletin of International Conference "Week of Natural Fibers within International Year of Natural Fibers" (vol. 1, pp. 45-48). Arad, Romany: FAO European Cooperative 
Research Network on Flax and other Bast Plants at the Institute of Natural Fibres, Poznan, Poland.

Nožinić, M., Šurica, R., Bojić, V., Bijelić, H. (2012). Ecological production of linseed and cold pressed linseed oil. In: Proceedings from the First International Congress of Ecologists “Ecological Spectrum”, 20-21 April 2012 (pp. 1039-1047). Banja Luka, Republic of Srpska, Bosnia and Herzegovina: University for Business Studies Banja Luka.

Nožinić, M., Šurica, R., Bojić, V., Bijelić, H. (2012). The influence of the climate changes to the agricultural production. In: Proceedings from the First International Congress of Ecologists "Ecological Spectrum”, 20-21 April 2012 (pp. 1081-1089). Banja Luka, Republic of Srpska, Bosnia and Herzegovina: University for Business Studies Banja Luka.

Panjan, M. (1968). Flax diseases. In: Diseases and Pests of Field Crops (pp. 347-349). Zagreb: Znanje (in Croatian).

Prasad, K. (1997). Dietary flaxseed in prevention of hypercholesterolemic atheorsclerosis. Atherosclerosis, 132 (1), 69-76.

Runge, M., Henriksen, P. S. (2007). Denmark's oldest flax industry. Fynske Minder, 145-165 (in Danish).

Simopoulos, A. R. (1999). Essential fatty acidis in health and chronic disease. Amer. J. Clin. Nutr., 70, 560-569.
Thompson, L. U. (1998). Experimental studies on lignans and cancer. Baillieres Clin. Endocrinal Metab., 12, 691-705.

Trkulja, V., Ostojić, I., Škrbić, R., Herceg, N., Petrović Danijela, Kovačević, Z. (2010). Ambrosia. Banja Luka: Society for Plant Protection in Bosnia and Herzegovina. 181 pp. (in Serbian).

Vapa, M., Vapa, L. (1997). Heavy metals and animals. In: Heavy Metals in the Environment (pp. 287-289). Novi Sad: Institute for Field and Vegetable Crops (in Serbian).

Westcott, N. D., Muir, A. D., Diederichsen, A. (2001). Flax lignan a health product for the new millennium. In: Proceedings of the Second Global Workshop “Bast Plants in the New Millennium”, 3-6 June 2001 (p. 54). Borovets, Bulgaria: Coordination Centre of the FAO European Cooperative Research Network on Flax and other Bast Plants at the Institute of Natural Fibres, Poznan, Poland.

Zimniewska, M., Kozlowski, R., Muzyczek, M., Florysiak, M. (2004). Towards more physiological friendly apparels made of natural fibers. In: Proceedings of the Third Global Workshop "Natural Fibers for Healthy Life", 24-28 October 2004 (CD form). Banja Luka, Bosnia and Herzegovina: FAO European Cooperative Research Network on Flax and other Bast Plants.

Received 15 April 2013

\section{PĀRSKATS PAR EL,ĽAS LINU AUDZĒĚŠAU BOSNIJĀ UN HERCEGOVINĀ}

Rakstā dots pārskats par eḷlas linu audzēšanu un zinātniskajiem pētījumiem par eḷlas liniem kopš 2004. gada, kad šo kultūru atsāka audzēt Bosnijā un Hercegovinā. Organisko linsēklu audzēšanai labākas perspektīvas, salīdzinājumā ar zemienēm, ir kalnu rajonos. To var izskaidrot galvenokārt ar nezāḷ neesamību $500 \mathrm{~m}$ augstumā virs jūras līmeņa. Pateicoties ekstensīvai linu audzēšanai, līdz šim nav novērotas linu slimības, kas varētu ietekmēt linsēklu kvalitāti. Pirmās visaptverošās tehnoloǵiskās analīzes par auksti ekstrahētas linsēklu ellıas kvalitāti no kalnu reğiona Petrovacas uzrādījušas unikālas kvalitātes īpašības. Šim kalnu reğionam raksturīga neskarta daba un saulains mikroklimats. Pētījumu rezultāti vairojuši interesi par linsēklu eḷıu un paaugstinājuši pašmāju linsēklu eḷıas cenu. 